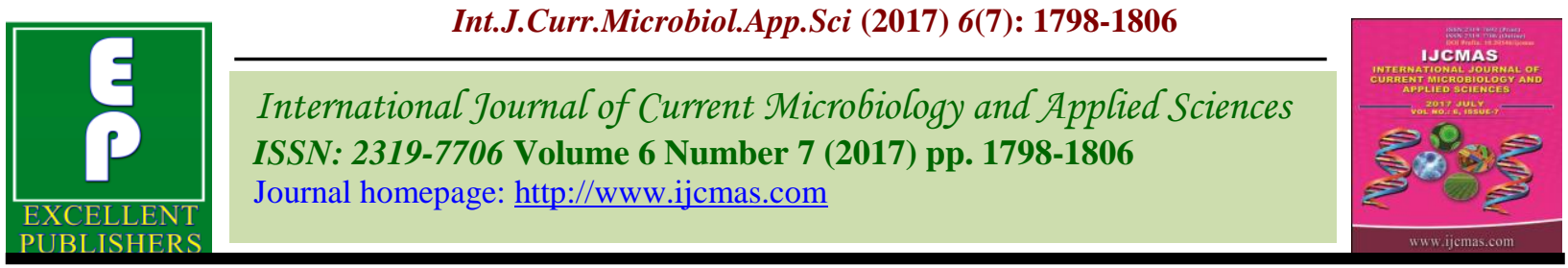

Original Research Article

https://doi.org/10.20546/ijcmas.2017.607.217

\title{
Variability, Correlation and Path Analysis in Advanced Generation of Aromatic Rice
}

\author{
L. Lakshmi*, M.V. Brahmeswara Rao, Ch. Surender Raju and S. Narender Reddy \\ Rice section farm, Agricultural Research Station, Rajendranagar, Hyderabad, India \\ *Corresponding author
}

Keywords

Kharif,

Scented rice,

Variability in

genotypes.

\section{Article Info}

Accepted:

19 June 2017

Available Online:

10 July 2017

\section{A B S T R A C T}

The present study was undertaken with the objective to determine the nature and magnitude of genetic variability, degree of association between yield and its component characters and their direct, indirect effects on grain yield in $\mathrm{F}_{7}$ generation of aromatic rice. The present experiment was carried out with fifty-five aromatic rice genotypes which were evaluated in randomized block design with three replications at Rice section farm, Agricultural Research Station, Rajendranagar, Hyderabad during Kharif, 2011. The results showed that sufficient amount of genetic variability was found among the genotypes for all the traits studied. Higher magnitude of genotypic and phenotypic coefficient of variation was recorded for number of productive tillers per hill, number of filled grains per panicle, 1000-grain weight, grain yield per plant, kernel length and L/B ratio indicates that these are least influence by environment. High heritability coupled with genetic advance as percent of mean was registered for plant height, number of productive tillers per plant, panicle length, number of filled grains per panicle, 1000-grain weight, grain yield per plant, kernel length and L/B ratio, suggesting preponderance of additive gene action in the expression of these traits. Correlation studies revealed positive significant correlation of grain yield per plant with panicle length, filled grains per panicle, 1000-grain weight, kernel length and L/B ratio at both the levels and number of productive tillers per hill at phenotypic level indicating these characters were important for yield improvement. Path coefficient analysis revealed that kernel length exerted the highest direct effect on grain yield followed by number of filled grains per panicle, 1000-grain weight, number of productive tillers per hill and plant height indicating the selection for these characters is likely to bring about on overall improvement in single plant yield directly.

\section{Introduction}

The scented rice has a unique position in international market but they are very low yielders in general condition. So it is very much essential to improve the yield to get a premium price in international market. The grain yield is a complex character and its expression depends upon its component characters. The knowledge on the association between yield and its component characters and their direct and indirect impact on grain yield will be helpful for the improvement of grain yield. So the present was undertaken to understand the association among yield and its component characters along with the nature and extent of direct and indirect effects of yield components on yield through correlation and path analysis in scented rice.

Variability in genotypes for yield and yield component traits forms the basic factor to be 
considered while making selection. Heritability along with genetic advance may provide a clearer picture for selection of a particular trait. The knowledge regarding relative contribution of individual traits to yield may be accomplished by correlation studies.

However, simple correlation does not provide the adequate information about the contribution of each factor towards yield. Therefore, the technique of path coefficient analysis is utilized to have an idea of direct and indirect contribution of a trait towards the yield, the end product. The present investigation was undertaken to gather some useful information on genetic variability, character association and path coefficient analysis in a set of 55 aromatic rice genotypes.

\section{Materials and Methods}

The experimental material for the present investigation consisted of 55 aromatic rice genotypes (Table 1). The experiment was conducted in randomized block design with 3 replications at Rice section farm, Agriculture Research Institute, Rajendranagar, Hyderabad during kharif, 2011. All the genotypes were sown separately in the nursery on raised beds. Thirty days old seedlings of each genotype were transplanted in two rows of $6 \mathrm{~m}$ length by adopting a spacing of $15 \times 15 \mathrm{~cm}$. The recommended agronomic and plant protection measures were followed to raise a healthy crop. Observations were recorded on five randomly selected plants per replication for the traits viz., days to $50 \%$ flowering, plant height $(\mathrm{cm})$, number of productive tillers per hill, panicle length $(\mathrm{cm})$, number of filled grains per panicle, 1000-grain weight $(\mathrm{g})$, grain yield per plant $(\mathrm{g})$, kernel length $(\mathrm{mm})$, kernel breadth $(\mathrm{mm})$ and Length/breadth ratio. The mean values over replications were used for statistical analysis.

\section{Results and Discussion}

The high GCV and PCV values observed for number of filled grains per panicle, 1000grain weight, grain yield per plant, kernel length, L/B ratio and only high PCV value for number of productive tillers per plant. The moderate GCV and PCV values observed for the traits plant height, panicle length, only moderate GCV value observed for number of productive tillers per plant. The values of genotypic and phenotypic and coefficients of variation were low for days to $50 \%$ flowering, kernel breadth.

Coefficients of variation studies indicated that the estimates of PCV were slightly higher than the corresponding GCV estimates for days to $50 \%$ flowering, plant height, panicle length, kernel length, 1000-grain weight and kernel breadth indicating that the characters were less influenced by the environment. Therefore, selection on the basis of phenotype alone can be effective for the improvement of these traits. The magnitude of PCV was higher than the corresponding GCV for the characters like number of productive tillers per plant, number of filled grains per panicle and grain yield per plant suggesting the influence of environment on the expression of these traits. All the characters exhibited high degree of broad sense heritability, which revealed that these characters are less influenced by environment and there could be greater correspondence between phenotypic and breeding values. Genetic advance as percent of mean was high for plant height, number of productive tillers per plant, panicle length, number of filled grains per panicle, 1000-grain weight, grain yield per plant, kernel length and L/B ratio, moderate for kernel breadth and it was low for days to $50 \%$ flowering. High heritability coupled with high genetic advance as percent of mean indicates the control of additive gene and selection may be effective for those characters (Table 2). 
Table.1 Estimates of variability, heritability (broad sense), genetic advance and genetic advance as per cent of mean for grain yield, its components and quality traits in aromatic rice genotypes

\begin{tabular}{|c|c|c|c|c|c|c|c|}
\hline S.No. & Character & Range & PCV (\%) & GCV (\%) & $\begin{array}{l}\text { Heritability in } \\
\text { Broad sense } \\
\qquad\left(\mathbf{h}^{2}{ }_{\text {bs }}\right)(\%)\end{array}$ & $\begin{array}{l}\text { Genetic } \\
\text { Advance } \\
\text { Per } \\
\text { cent (at 5\%) }\end{array}$ & $\begin{array}{l}\text { GA as per } \\
\text { cent of } \\
\text { mean } \\
\quad(\text { at } 5 \%)\end{array}$ \\
\hline 1. & Days to $50 \%$ flowering & $100.67-117.00$ & 4.31 & 3.73 & 74.8 & 7.19 & 6.64 \\
\hline 2. & Plant height $(\mathrm{cm})$ & $103.25-160.50$ & 10.35 & 10.20 & 97.1 & 26.80 & 20.70 \\
\hline 3. & $\begin{array}{l}\text { Number of productive tillers per } \\
\text { plant }\end{array}$ & $6.08-15.00$ & 21.77 & 15.71 & 52.1 & 2.20 & 23.36 \\
\hline 4. & Panicle length $(\mathrm{cm})$ & $19.00-29.25$ & 10.88 & 10.47 & 92.7 & 5.15 & 20.78 \\
\hline 5. & Number of filled grains per panicle & $108.53-459.07$ & 40.06 & 39.11 & 95.3 & 165.83 & 78.66 \\
\hline 6. & 1000-grain weight (g) & $7.00-22.85$ & 30.99 & 30.36 & 96.0 & 9.23 & 61.29 \\
\hline 7. & Grain yield per plant $(\mathrm{g})$ & $5.46-30.89$ & 29.66 & 25.14 & 71.8 & 7.61 & 43.88 \\
\hline 8. & Kernel length (mm) & $3.20-7.47$ & 28.42 & 28.10 & 99.7 & 3.01 & 57.80 \\
\hline 9. & Kernel breadth (mm) & $1.52-2.27$ & 9.44 & 9.32 & 97.3 & 0.33 & 18.93 \\
\hline 10 & L/B Ratio & $1.80-4.90$ & 33.23 & 33.19 & 99.7 & 2.07 & 68.28 \\
\hline 11. & Kernel length after cooking (mm) & $5.25-12.75$ & 22.29 & 22.19 & 99.1 & 3.83 & 45.49 \\
\hline 12. & Kernel elongation ratio & $1.30-2.03$ & 10.14 & 9.43 & 86.4 & 0.29 & 18.06 \\
\hline 13. & Volume expansion ratio & $3.25-5.50$ & 10.84 & 8.78 & 65.7 & 0.61 & 14.66 \\
\hline
\end{tabular}


Table.2 Estimation of phenotypic and genotypic correlation coefficients between yield and its component characters in aromatic rice

\begin{tabular}{|c|c|c|c|c|c|c|c|c|c|c|c|}
\hline Character & & $\begin{array}{c}\text { Days to } \\
50 \% \\
\text { flowering }\end{array}$ & $\begin{array}{c}\text { Plant } \\
\text { height }(\mathrm{cm})\end{array}$ & $\begin{array}{c}\text { Panicle } \\
\text { length }(\mathrm{cm})\end{array}$ & $\begin{array}{l}\text { Number of } \\
\text { filled } \\
\text { grains per } \\
\text { panicle }\end{array}$ & $\begin{array}{l}\text { 1000-grain } \\
\text { weight }(g)\end{array}$ & $\begin{array}{c}\text { Number of } \\
\text { productive } \\
\text { tillers per } \\
\text { plant }\end{array}$ & $\begin{array}{c}\text { Kernel } \\
\text { length } \\
(\mathrm{mm})\end{array}$ & $\begin{array}{c}\text { Kernel } \\
\text { breadth } \\
(\mathbf{m m})\end{array}$ & $\mathrm{L} / \mathrm{B}$ ratio & $\begin{array}{c}\text { Grain yield } \\
\text { per } \\
\text { plant }(g)\end{array}$ \\
\hline \multirow{2}{*}{$\begin{array}{c}\text { Days to } \\
50 \% \text { flowering }\end{array}$} & $\mathbf{G}$ & 1.000 & 0.0750 & $-0.4995 * *$ & 0.0259 & $-0.3345^{* *}$ & $0.1812^{*}$ & $-0.4193 * *$ & 0.1432 & $-0.3885 * *$ & $-0.3742 * *$ \\
\hline & $\mathbf{P}$ & 1.000 & 0.0601 & $-0.4111 * *$ & 0.0408 & $-0.2953 * *$ & $0.1731 *$ & $-0.3665 * *$ & 0.1061 & $-0.3362 * *$ & $-0.2046^{* *}$ \\
\hline \multirow{2}{*}{ Plant height(cm) } & $\mathbf{G}$ & & 1.000 & $0.3119 * *$ & 0.1057 & -0.1216 & $-0.2107 * *$ & $-0.2681 * *$ & $0.3702 * *$ & $-0.3167 * *$ & -0.0154 \\
\hline & $\mathbf{P}$ & & 1.000 & $0.2943 * *$ & 0.1045 & -0.1171 & -0.1448 & $-0.2645 * *$ & $0.3521 * *$ & $-0.3105 * *$ & -0.0107 \\
\hline \multirow[t]{2}{*}{ Panicle length(cm) } & $\mathbf{G}$ & & & 1.000 & $-0.2093 * *$ & $0.6033 * *$ & -0.0690 & $0.5897 * *$ & -0.1108 & $0.5435^{* *}$ & $0.2651^{* *}$ \\
\hline & $\mathbf{P}$ & & & 1.000 & $-0.1748 *$ & $0.5593 * *$ & -0.0198 & $0.5668 * *$ & -0.1085 & $0.5245^{* *}$ & $0.2280 * *$ \\
\hline \multirow{2}{*}{$\begin{array}{l}\text { Number of filled } \\
\text { grains per panicle }\end{array}$} & G & & & & 1.000 & $-0.7554 * *$ & $-0.3197 * *$ & $-0.6452 * *$ & -0.0663 & $-0.5522 * *$ & $0.2025 * *$ \\
\hline & $\mathbf{P}$ & & & & 1.000 & $-0.7185 * *$ & $-0.1878^{*}$ & $-0.6314 * *$ & -0.0614 & $-0.5409 * *$ & $0.2316 * *$ \\
\hline \multirow{2}{*}{1000 -grain weight $(g)$} & G & & & & & 1.000 & 0.0944 & $0.9189 * *$ & -0.1282 & $0.8315^{* *}$ & $0.2019 * *$ \\
\hline & $\mathbf{P}$ & & & & & 1.000 & 0.0710 & $0.9009 * *$ & -0.1115 & $0.8123^{* *}$ & $0.1707 *$ \\
\hline \multirow{2}{*}{$\begin{array}{l}\text { Number of productive } \\
\text { tillers per plant }\end{array}$} & G & & & & & & 1.000 & 0.0604 & 0.0046 & 0.0461 & 0.1260 \\
\hline & $\mathbf{P}$ & & & & & & 1.000 & 0.0393 & 0.0143 & 0.0261 & $0.3048 * *$ \\
\hline \multirow{2}{*}{ Kernel length(mm) } & $\mathbf{G}$ & & & & & & & 1.000 & $-0.449 * *$ & $0.9778 * *$ & $0.2237 * *$ \\
\hline & $\mathbf{P}$ & & & & & & & 1.000 & $-0.440 * *$ & $0.9765^{* *}$ & $0.1822 *$ \\
\hline \multirow{2}{*}{ Kernel breadth(mm) } & $\mathbf{G}$ & & & & & & & & 1.000 & $-0.6179 * *$ & -0.1367 \\
\hline & $\mathbf{P}$ & & & & & & & & 1.000 & $-0.6124 * *$ & -0.1093 \\
\hline \multirow{2}{*}{$\mathrm{L} / \mathrm{B}$ ratio } & $\mathbf{G}$ & & & & & & & & & 1.000 & $0.2079 * *$ \\
\hline & $\mathbf{P}$ & & & & & & & & & 1.000 & $0.1699 *$ \\
\hline
\end{tabular}

$\mathbf{P}$-represents phenotypic correlation coefficient; G- represents genotypic correlation coefficient;

$5 \%$ level of significance, $* * 1 \%$ level of significance 
Table.3 Estimation of genotypic and phenotypic direct and indirect effects between yield and yield attributing characters in aromatic rice

\begin{tabular}{|c|c|c|c|c|c|c|c|c|c|c|c|}
\hline Character & & $\begin{array}{l}\text { Days to } \\
50 \% \\
\text { flowering }\end{array}$ & $\begin{array}{c}\text { Plant } \\
\text { height }(\mathrm{cm}\end{array}$ & $\begin{array}{c}\text { Panicle } \\
\text { length }(\mathrm{cm})\end{array}$ & $\begin{array}{c}\text { Number of } \\
\text { productive } \\
\text { tillers per } \\
\text { plant } \\
\end{array}$ & $\begin{array}{c}\text { Number of } \\
\text { filled grains } \\
\text { per panicle }\end{array}$ & $\begin{array}{l}\text { 1000-grain } \\
\text { weight }(g)\end{array}$ & $\begin{array}{c}\text { Kernel } \\
\text { length }(\mathbf{m m})\end{array}$ & $\begin{array}{c}\text { Kernel } \\
\text { breadth }(\mathbf{m m})\end{array}$ & L/B ratio & $\begin{array}{c}\text { Correlation } \\
\text { with grain } \\
\text { yield per } \\
\text { plant }(r) \\
\end{array}$ \\
\hline \multirow{2}{*}{$\begin{array}{l}\text { Days to } \\
50 \% \text { flowering }\end{array}$} & $\mathbf{G}$ & -0.2211 & -0.0167 & 0.1105 & -0.0401 & -0.0057 & 0.0740 & 0.0927 & -0.0317 & 0.0859 & $-0.3742 * *$ \\
\hline & $\mathbf{P}$ & -0.0753 & -0.0045 & 0.0310 & -0.0130 & -0.0031 & 0.0223 & 0.0276 & -0.0080 & 0.0253 & $-0.2046 * *$ \\
\hline \multirow{2}{*}{ Plant height(cm) } & $\mathbf{G}$ & 0.0234 & 0.3110 & 0.0970 & -0.0655 & 0.0329 & -0.0378 & -0.0834 & 0.1151 & -0.0985 & -0.0154 \\
\hline & $\mathbf{P}$ & 0.0123 & 0.2041 & 0.0601 & -0.0296 & 0.0213 & -0.0239 & -0.0540 & 0.0719 & -0.0634 & -0.0107 \\
\hline \multirow{2}{*}{$\begin{array}{c}\text { Panicle } \\
\text { length }(\mathrm{cm})\end{array}$} & $\mathbf{G}$ & 0.2296 & -0.1434 & -0.4597 & 0.0317 & 0.0962 & -0.2773 & -0.2711 & 0.0509 & -0.2498 & $0.2651 * *$ \\
\hline & $\mathbf{P}$ & 0.1126 & -0.0806 & -0.2738 & 0.0054 & 0.0479 & -0.1531 & -0.1552 & 0.0297 & -0.1436 & $0.2280 * *$ \\
\hline \multirow{2}{*}{$\begin{array}{c}\text { Number of } \\
\text { productive tillers } \\
\text { per plant }\end{array}$} & $\mathbf{G}$ & 0.0843 & -0.0980 & -0.0321 & 0.4650 & -0.1487 & 0.0439 & 0.0281 & 0.0022 & 0.0214 & 0.1260 \\
\hline & $\mathbf{P}$ & 0.0801 & -0.0670 & -0.0092 & 0.4626 & -0.0869 & 0.0328 & 0.0182 & 0.0066 & 0.0121 & $0.3048^{* *}$ \\
\hline \multirow{2}{*}{$\begin{array}{c}\text { Number of filled } \\
\text { grains per } \\
\text { panicle }\end{array}$} & $\mathbf{G}$ & 0.0314 & 0.1282 & -0.2540 & -0.3881 & 1.2136 & -0.9168 & -0.7830 & -0.0804 & -0.6702 & $0.2025^{* *}$ \\
\hline & $\mathbf{P}$ & 0.0403 & 0.1033 & -0.1728 & -0.1856 & 0.9884 & -0.7101 & -0.6240 & -0.0607 & -0.5346 & $0.2316^{* * *}$ \\
\hline \multirow{2}{*}{$\begin{array}{c}\text { 1000-grain } \\
\text { weight }(\mathrm{g})\end{array}$} & $\mathbf{G}$ & -0.2321 & -0.0844 & 0.4187 & 0.0655 & -0.5242 & 0.6939 & 0.6377 & -0.0889 & 0.5770 & $0.2019 * *$ \\
\hline & $\mathbf{P}$ & -0.0869 & -0.0344 & 0.1644 & 0.0209 & -0.2112 & $\mathbf{0 . 2 9 3 9}$ & 0.2648 & -0.0328 & 0.2388 & $0.1707 *$ \\
\hline $\begin{array}{c}\text { Kernel } \\
\text { length }(\mathbf{m m})\end{array}$ & $\mathbf{P}$ & -0.8545 & -0.6168 & 1.3215 & 0.0915 & -1.4722 & 2.1006 & 2.3317 & -1.0268 & 2.2769 & $0.1822^{*}$ \\
\hline \multirow{2}{*}{$\begin{array}{c}\text { Kernel } \\
\text { breadth }(\mathbf{m m}) \\
\end{array}$} & G & -0.0474 & -0.1226 & 0.0367 & -0.0015 & 0.0220 & 0.0425 & 0.1491 & -0.3313 & 0.2047 & -0.1367 \\
\hline & $\mathbf{P}$ & -0.0161 & -0.0533 & 0.0164 & -0.0022 & 0.0093 & 0.0169 & 0.0666 & -0.1514 & 0.0927 & -0.1093 \\
\hline \multirow{2}{*}{$\mathrm{L} / \mathrm{B}$ ratio } & $\mathbf{G}$ & 0.9423 & 0.7680 & -1.3181 & -0.1118 & 1.3393 & -2.0165 & -2.3716 & 1.4985 & -2.4253 & $0.2079 * *$ \\
\hline & $\mathbf{P}$ & 0.5830 & 0.5384 & -0.9096 & -0.0452 & 0.9381 & -1.4088 & -1.6935 & 1.0621 & -1.7342 & $0.1699^{*}$ \\
\hline
\end{tabular}

Phenotypic residual effect $=0.6947$

P- represents phenotypic correlation coefficient;

Genotypic residual effect $=0.6528$

Bold values- direct effects

G- represents genotypic correlation coefficient.

Normal values- indirect effects 

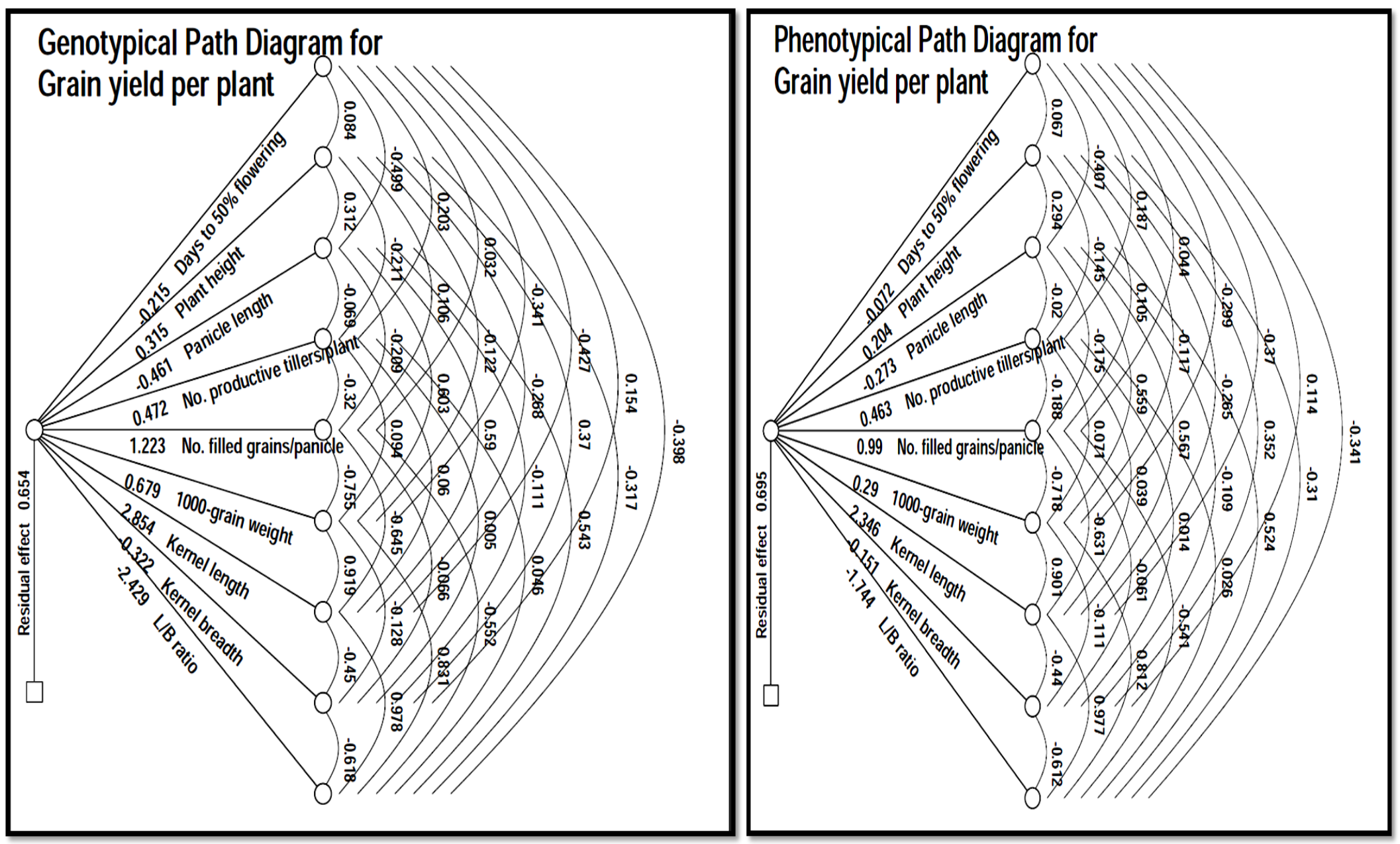
Genotypic and phenotypic correlations revealed that grain yield per plant had significant positive association with panicle length $\left(0.2651^{* *} / 0.2280^{* *}\right)$, number of filled grains per panicle $\left(0.2025^{* *} / 0.2316^{* *}\right)$, 1000 -grain weight $\left(0.2019^{* *} / 0.1707^{*}\right)$, kernel length $(0.2237 * * / 0.1822 *)$ and $\mathrm{L} / \mathrm{B}$ ratio $(0.2079 * * / 0.1699 *)$ and at phenotypic level with number of productive tillers per hill $(0.3048 * *)$.Similar kind of association was revealed by Sadhukhan and Chattopadhyay (2000) for kernel length, Nayak et al., (2001) for panicle length, Madhavilatha et al., (2005) for panicle length and 1000 grain weight, Patil and Sarawgi (2005) for number of filled grains per panicle, Tayeng and Singh (2006) for panicle length. It indicated that grain yield could be increased whenever there was an increase in characters that showed positive and significant association with grain yield. Hence, these characters could be considered as criteria for selection for higher yield as these were mutually and directly associated with grain yield.

It was observed that days to $50 \%$ flowering was recorded significant negative correlation with grain yield per plant at both genotypic and phenotypic levels. Similar results were reported by Surek and Beser (2003), Qamar et al., (2005), Anbumalarmathi and Nadarajan (2008), kole et al., (2008), Yadav et al., (2011),Ravindra Babu et al., (2012), Seyoum et al., (2012). Hence, selection for early flowering types will have simultaneous improvement on the other trait and finally increase the grain yield.

Plant height registered significant positive association with panicle length and kernel breadth at both genotypic and phenotypic levels. It suggests that interdependency of these characters should be given due consideration in selection programme. Similar results were reported by Kole et al., (2008), Khan et al., (2009), Sadeghi (2011), Ravindra
Babu et al., (2012) for panicle length, Sabesan et al., (2009) for panicle length and kernel breadth. Negative correlation of plant height with paddy yield showed that paddy yield in fine grain rice can be increased with reduction in plant height. Thus semi dwarf genotypes will be preferred to boost up paddy yields in rice.

Panicle length exhibited positive and significant association with 1000 grain weight followed by kernel length and L/B ratio at both the levels. Increased panicle length can be considered as one of the important attribute for improvement of grain yield due to its significant positive correlation with grain yield and other traits such as kernel length, 1000-grain weight (Table 3).

Number of filled grains per panicle had negative and significant association with 1000 grain weight, number of productive tillers per hill, kernel length and L/B ratio at both the levels. 1000- grain weight had positive and significant association with kernel length and $\mathrm{L} / \mathrm{B}$ ratio at both the levels. Number of productive tillers per hill recorded positive and non-significant association with kernel length, kernel breadth and L/B ratio at both the levels. Kernel length had had significant positive correlation with $\mathrm{L} / \mathrm{B}$ ratio which was reported by Reddy et al., (2006) and it had negative significant correlation with kernel breadth at both levels which was reported by Sadeghi (2011) at phenotypic level. Kernel breadth recorded a negative and significant association with $\mathrm{L} / \mathrm{B}$ ratio and non-significant association with grain yield per plant at both the levels.

Correlation studies revealed that the grain yield per plant showed positive significant association with panicle length, number of filled grains per panicle, 1000-grain weight, kernel length and L/B ratio at genotypic and phenotypic levels and number of productive 
tillers per hill at only phenotypic level indicatinga simultaneous selection for these characters would be more advantageous for yield improvement in rice.

Path coefficient analysis revealed that kernel length exerted the highest direct effect on grain yield followed by number of filled grains per panicle, 1000-grain weight, number of productive tillers per hill and plant height indicating the selection for these characters is likely to bring about on overall improvement in single plant yield directly. Similar results were noticed by Krishnappa et al., (2009), Bagheri et al., (2011) and Singh et al., (2011).

Days to $50 \%$ flowering had negative direct effect on grain yield per plant. It showed indirect positive influence on grain yield through panicle length, 1000-grain weight, kernel length and L/B ratio. Plant height had positive direct effect on grain yield and its positive indirect effects on grain yield through days to $50 \%$ flowering, panicle length, number of filled grains per panicle and kernel breadth. Number of productive tillers per hill had positive direct effect on grain yield and its positive indirect effects via days to $50 \%$ flowering, 1000-grain weight, kernel length, kernel breadth and L/B ratio. Panicle length exhibited negative direct effect on grain yield and it showed high positive indirect effects through days to $50 \%$ flowering, number of filled grains per panicle, number of productive tillers per plant and kernel breadth. Hence it showed positive significant correlation with grain yield.

Number of filled grains per panicle had positive direct effect on grain yield and it showed positive indirect effects via days to $50 \%$ flowering and plant height. 1000-grain weight expressed positive direct effect on grain yield and the indirect effects through panicle length, number of productive tillers, kernel length and L/B ratio were positive.
Kernel length registered positive direct effect on grain yield and showed positive indirect effects through panicle length, number of productive tillers per hill, 1000-grain weight and $\mathrm{L} / \mathrm{B}$ ratio. Kernel breadth had negative direct effect on grain yield and showed positive indirect effects through panicle length, number of filled grains per panicle, 1000-grain weight, kernel length and L/B ratio. $\mathrm{L} / \mathrm{B}$ ratio had negative direct effect on grain yield and showed positive indirect effects through days to $50 \%$ flowering, plant height, number of filled grains per panicle and kernel breadth.

Critical analysis of the results by path analysis revealed that the traits kernel length followed by number of filled grains per panicle, 1000grain weight, number of productive tillers per hill and plant height were directly influencing the grain yield per plant. Hence, these traits were considered as important attributes in formulating selection criterion for achieving desired targets.

\section{References}

Bagheri, N., Babaeianjelodar, N., and Aram Pasha. 2011. Path coefficient analysis for yield and yield components in diverse rice (Oryza sativa L.) genotypes. Biharean Biologist, 5(1): 32-35.

Khan, A.S., Imran, M., and Ashfaq, M. 2009. Estimation of genetic variability and correlation for grain yield components in rice (Oryza sativa L.). AmericanEurasian J. Agric. Environ. Sci., 6(5): 585-590.

Kole, P.C., Chakraborty, N.R., and Bhat, J.S. 2008. Analysis of variability, correlation and path coefficients in induced mutants of aromatic non-basmati rice. Tropical Agri. Res. Extension, 11: 60-64.

Krishnappa, M.R., Chandrappa, H.M., and Shadakshari, Y.G. 2009. Path coefficient analysis in hill zone rice (Oryza sativa 
L.) genotypes of Karnataka. Environ. Ecol., 27(3): 1194-1196.

Madhavilatha, L., Sekhar, M.R., Suneetha, Y., and Srinivas, T. 2005. Genetic variability, correlation and path analysis for yield and quality traits in rice (Oryza sativa L.). Res. Crops, 6(3): 527-534.

Nayak, A.R., Chaudhury, D., and Reddy, J.N. 2001. Correlation and path analysis in scented rice (Oryzasativa L). Indian $J$. Agric. Res., 35(3): 186 -189.

Patil, P.V. and Sarawgi, A.K. 2005. Studies on genetic variability, correlation and pathanalysis in traditional aromatic rice accessions. Annals of Plant Physiol., 19(1): 92-95.

Qamar, Z.U., Cheema, A.A., Ashraf, M., Rashid, M., and Tahir, G.R. 2005. Association analysis of some yield influencing traits in aromatic and non aromatic rice. Pak. J. Bot., 37: 613-627.

Ravindra Babu, V., Shreya, K., Kuldeep Singh Dangi, Usharani, G., and Siva Shankar, A. 2012. Correlation and path analysis studies in popular rice hybrids of India. Int. J. Scientific and Res. Publications, 2(3).

Reddy, M.Y., Lavanya, G.R., and Babu, G.S. 2006. Estimation of genetic divergence in irrigated early type rice germplasm. Res. Crops, 7(2): 433-436.

Sabesan, T., Suresh, R., and Saravanan, K. 2009. Genetic variability and correlation for yield and grain quality characters of rice grown in coastal saline low land of Tamilnadu. J. Plant Breeding, 1: 56-59.

Sadeghi, S.M. 2011. Heritability, phenotypic correlation and path coefficient studies for some agronomic characters in land race rice varieties. World Appl. Sci. J., 13(5): 1229-1233.

Sadhukhan, R.N. and Chattopadhyay, P. 2000. Variability and character association between yield attributes and grain quality in aromatic rice. $J$. Interacademicia, 4(4): 494-497.

Seyoum, M., Alamerew, S., and Bantte, K. 2012. Genetic variability, heritability, correlation coefficient and path analysis for yield and yield related traits in upland rice (Oryza sativa L.). J. Plant Sci., 7(1): 13-22.

Singh, B.N., Verma. O.P., and Shweta Tripathi Dwivedi, D.K. 2011. Correlation and path coefficient analysis in scented rice (Oryza sativa L.) under sodicity. Environ. Ecol., 29(3B): 1550-1556.

Surek, H. and Beser, N. 2003. Correlation and path coefficient analysis for some yieldrelated traits in rice (Oryza sativa L.) under the race conditions. Turk. J. Agric. For., 27: 77-83.

Tayeng, T., and Singh, M.R.K. 2006. Correlation and path analysis in some early rice (Oryza sativa L) genotypes under pre kharif conditions of Manipur Valley. Environ. Ecol., 24(2): 265-267.

Yadav, S.K., Pandey, P., Kumar, B., and Suresh, B.G. 2011. Genetic architecture, inter-relationship and selection criteria for yield improvement in rice (Oryza sativa L.). Pakistan J. Biol. Sci., 14(9): 540-545.

\section{How to cite this article:}

Lakshmi, L., M.V. Brahmeswara Rao, Ch. Surender Raju and Narender Reddy, S. 2017. Variability, Correlation and Path Analysis in Advanced Generation of Aromatic Rice. Int.J.Curr.Microbiol.App.Sci. 6(7): 1798-1806. doi: https://doi.org/10.20546/ijcmas.2017.607.217 